\title{
Pengembangan $E$-Modul IPA Bermuatan Tes Online untuk Meningkatkan Hasil Belajar
}

\author{
Hilmania Dwi Lestari \\ Universitas Pendidikan Ganesha, Singaraja \\ e-mail: hilmania.dwi.lestari@undiksha.ac.id \\ Desak Putu Parmiti \\ Universitas Pendidikan Ganesha, Singaraja \\ e-mail:desak.parmiti@undiksha.ac.id
}

\begin{abstract}
Abstrak
Penelitian ini dilatarbelakangi oleh sumber belajar yang digunakan oleh guru hanya berupa buku paket. Maka dari itu perlu dikembangkan modul elektronik bermuatan tes online. Penelitian ini bertujuan untuk mengembangkan e-modul IPA bermuatan tes online dan efektifitasnya untuk meningkatkan hasil belajar. Model pengembangan yang digunakan yaitu model ADDIE. Teknik pengumpulan data yang digunakan adalah dengan metode wawancara, pencatatan dokumen, kuesioner, dan tes. Analisis data menggunakan analisis deskriptif kumalitatif, kuantitatif, Hasil analisis menunjukkan terdapat perbedaan yang signifikan hasil belajar IPA antara sebelum dan sesudah menggunakan E-Modul IPA bermuatan tes online pada siswa kelas VII, yang dibuktikan dengan $t_{\text {hitung }}=-31,27$ untuk $\mathrm{db}=68$ dan taraf signifikan $5 \% \mathrm{t}_{\text {tabel }}=1$. Berarti emodul bermuatan tes online efektif untuk meningkatkan hasil belajar.
\end{abstract}

Kata kunci: E-Modul, Model Pengembangan,Tes Online

\begin{abstract}
This research is motivated by the textbook as the only learning resources used by the teachers. Therefore, it is necessary to develop an electronic module containing online tests. This study aims to develop an e-module containing online tests and to find out its effectiveness to improve learning outcomes. The development model used is the ADDIE model. Data collection techniques used were interviews, document recording, questionnaires, and tests. The data were analyzed in both qualitatively and quantitatively. The results of the analysis showed that there were significant differences in the learning outcomes of science between before and after the implementation of the E-Module containing online tests for the $7^{\text {th }}$-grade students, as evidenced by $t_{\text {count }}=-31.27$ for $\mathrm{db}=68$ and significant level of $5 \% \mathrm{t}_{\mathrm{table}}=1$. This means that the E-Module containing online tests are effective in improving students' learning outcomes.
\end{abstract}

Keywords : E-Module, Development Model, Tes Online

\section{Pendahuluan}

Kemajuan teknologi didunia ini sudah semakin meningkat, hampir seluruh kegiatan yang dilakukan sehari-hari memakai sistem teknologi. Begitu pula dengan pemanfaatan teknologi dalam dunia pendidikan. Seperti yang diungkapakan oleh Getuno, dkk (2015) "Teaching and learning worldwide has gone through a transformation that has seen traditional delivery of learning material augmanted by the use of information and Communication Technologies (ICT)". (Belajar dan mengajar diseluruh dunia telah melalui transformasi yang bisa dilihat melalui penyajian pembelajaran tradisional materi ditambah dengan penggunaan Teknologi Informasi dan Komunikasi (ICT). Kemajuan teknologi saat ini saat mendukung kegiatan manusia dalam melaksanakan aktifitasnya. Terdapat banyak bidang yang memanfaatkan perkembangan teknologi ini, yang telah disebutkan, yaitu dalam bidang pendidikan. Akan tetapi, banyak pengguna yang mensalahgunakan teknologi dan internet. Seperti contohnya pada penggunaan gadget secara terus menerus yang tidak penting, menggunakan internet secara negatif seperti penyamaran, berita hoax, dan media-media yang tidak pantas.

Didalam dunia pendidikan teknologi yang semakin pesat ini perlu dimanfaatkan dalam metode pembelajaran, baik untuk memmbuat media pembelajaran yang inovatif ataupun sebagai sumber informasi dan lainnya. Sistem teknologi akan memudahkan para guru atau siswa siswa disekolah sesuai dengan manfaat yang diambil oleh masing-masing pribadi. Menurut AECT 2008 (dalam Arsyad, 2017), teknolog pendidikan yaitu kajian dan praktek etis untuk memfasilitasi belajar dan membenahi kinerja dengan menghasilkan, menggunakan, dan mengelola proses dan sumber-sumber teknologi yang sesuai.

Dalam kelanjutan teknolog pembelajaran menggambarkan satu pengetahuan tertentu yang tidak hanya terbatas pada media dalam bentuk peralatan fisik semata, tetapi kajian dan praktik etis dalam merancang, mengembangkan, menggunakan, mengelola, dan mengevaluasi sistem dan sumber teknologi yang patut memfasilitasi belajar dan memperbarui kinerja pendidik, pelajar, dan lembaga kependidikan. Media pembelajaran yang dilihat sebagai bentuk sarana koneksi berupa hardware dan software merupakan bagian kecil dari teknolog pembelajaran yang perlu diciptakan untuk kepentingan pembelajaran supaya memperoleh kedayagunaan dalam metode pembelajaran. 
Menurut AECT (dalam sadiman, dkk, 2006) media adalah "segala bentuk dan saluran yang digunakan orang untuk menyalurkan pesan/informasi". Berdasarkan paparan tersebut dapat diketahui bahan belajar merupakan bentuk benda yang diterapkan pendidikan untuk menyalurkan pesan/informasi kepada siswa. Maka, berdasarkan paparan tersebut materi ajar dapat digolongkan sebagai media pembelajaran.

Media pembelajaran yang cocok untuk diterapkan dalam metode pembelajaran memiliki karakter tersendiri. Satu diantaranya yakni desain pesan yang terdapat dalam media pembelajaran. Menurut Sudarma, dkk (2015) Desaian pesan yang disampaikan adalah "pesan pembelajaran harus dikemas dengan cara menarik dan mudah dipahami". Karena, pesan pembelajaran yang tidak didesain berdasarkan teori desain pesan cenderung akan sulit mempengaruhi proses pembelajaran. Bahan ajar bilamana diterapkan dengan metode pembelajaran yang sesuai dengan keperluan pendidik dan siswa dapat digunakan dengan baik merupakan faktor komponen penting yang mampu meningkatkan kualitas pembelajaran.

Saat ini, beberapa sekolah belum menerapkan metode pembelajaran dengan sistem teknologi yang berkembang pada saat ini. Padahal disetiap sekolah sudah dilengkapi dengan beberapa alat pendukung, seperti contoh komputer dan bahkan beberapa siswanya juga telah memiliki smartphone atau laptop dirumahnya. Banyak sekolah yang beranggapan jika pembelajaran menggunakan sistem teknologi, akan berdampak negatif atau pembelajaran tidak akan berjalan dengan sempurna. Hal ini disebabkan karena para guru masih menerapkan pembelajaran konvensional. Berdasarkan hasil analisis kebutuhan guru dan siswa kelas VII di SMPN 3 Singaraja telah terjadi kesenjanagan, harapan, dan kenyataan dalam mata pelajaran IPA khususnya dalam hasil belajar siswa. Ditemukan permasalahan seperti rendahnya pengetahuan yang dimiliki siswa. Selain itu faktor penyebabnya adalah pembelajaran dikelas masih menggunakan buku paket dan dominan menggunakan pembelajaran konvensional saat menyampaikan materi walaupun sesekali menerangkan dengan menggunakan bantuan media powerpoint. Pembelajaran yang berlangsung dengan metode ceramah, kurang berkesan dibenak siswa. Siswa belajar dengan menghafal materi yang ditulis, tetapi beberapa hari kemudian lupa dengan materi yang telah dipelajari tersebut. Menurut siswa, pembelajaran dengan metode ceramah kurang mendukung kemampuan siswa mengingat, sehingga hasil belajar yang diperoleh masih rendah.

Melalui kemajuan teknologi informasi, pengembangan pembelajaran dalam memperbarui penyampaian bahan belajar mengenai ini modul cetak, merupakan modul yang dikemas dalam format digital atau diketahui dengan sebutan modul elektronik (e-modul). Menurut Wirawan (2017:3), e-modul yakni bahan ajar yang didesain secara terstruktur berdasarkan kurikulum dan disusun dalam satuan waktu tertentu, yang dikemas menggunakan perangkat elektronik seperti komputer atau android. E-modul mengolah bagian-bagian yang termuat dalam modul cetak pada biasanya. Perbandingannya hanya pada penyampaian fisik E-Modul yang menggunakan perangkat komputer. E-Modul IPA ini mengintegrasikan tes formatif dalam bentuk tes online. Tes online dipilih lantaran dengan cepat memunculkan skor/nilai yang diperoleh siswa. Dengan itu guru segera mengetahui kinerja siswa dan guru cepat melakukan pemeriksaan untuk siswa yang belum memenuhi nilai yang ditentukan. Diharapkan dengan dikembangkannya E-Modul IPA untuk kelas VII, hasil kognitif siswa misalnya pengetahuan, pemahaman, aplikasi, sintetis, dan penilaian searah dengan tujuan pendidikan dan pengajaran.

Sesuai dengan kebutuhan guru dalam mengatasi permasalahan dalam proses pembelajaran pada mata pelajaran IPA, dirasa perlu adanya suatu inovasi baru dalam pengembangan sistem pembelajaran yang lebih menarik, interaktif dan efektif serta efisien dalam pemanfaatannya. Sehubungan dengan hal tersebut, dipandang perlu untuk mengembangkan E-Modul IPA Bermuatan Tes Online siswa kelas VII di SMPN 3 Singaraja.

Adapun tujuan dari penelitian pengembangan ini adalah untuk mengetahui efektivitas $E$-Modul IPA Bermuatan Tes Online terhadap hasil belajar siswa kelas VII di SMPN 3 Singaraja.

\section{Metode}

Jenis penelitian ini adalah penelitian pengembangan. Penelitian ini dilaksanakan pada 8 Januari 2019 sampai 22 November 2019. Populasi dalam penelitian ini adalah seluruh siswa kelas VII di SMP Negeri 3 Singaraja yang berjumlah 35 siswa. Prosedur pengembangan yang digunakan mengacu pada model pengembangan yang dipilih yaitu model ADDIE yang terdiri dari 5 tahap, Adapun tahapan dalam melakukan pengembangan $e$-modul, yaitu sebagai berikut.

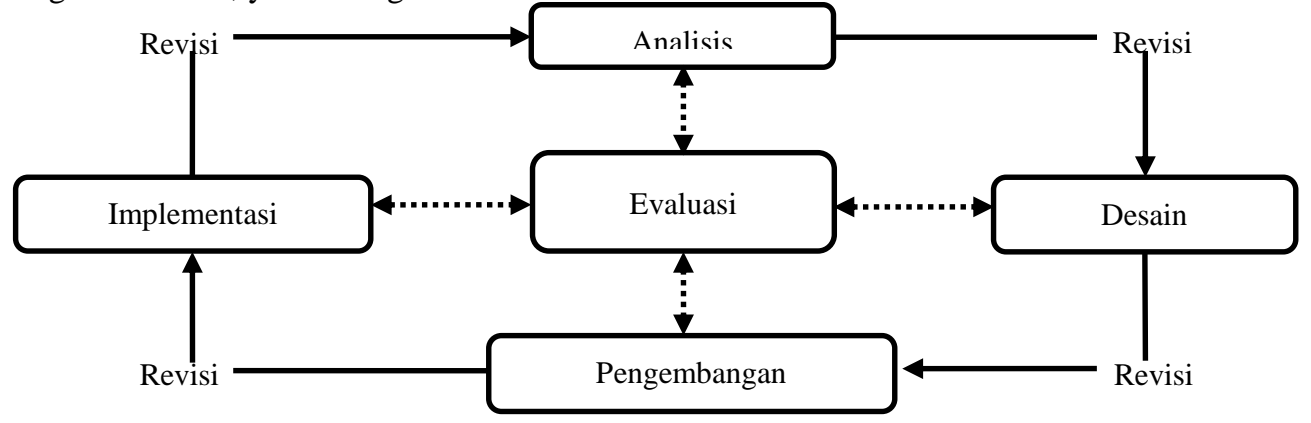

Gambar 1. Bagan Prosedur Penelitian Pengembangan

(Sumber: Tegeh, 2014) 
Penelitian ini menggunakan empat metode pengumpulan data yaitu metode observasi, wawancara, pencatatan dokumen, kuesioner, dan tes. (1) Metode kuesioner merupakan cara memperoleh atau mengumpulkan data dengan mengirimkan suatu daftar pertanyaan atau pernyataan kepada responden atau subjek penelitian (Agung, 2014:99). 92) Metode wawancara adalah suatu metode pengumpulan data dengan cara melakukan tanya jawab yang sistematis, dan hasil tanya jawab ini dicatat atau direkam secara cermat (Agung, 2014:97). (3) Pencatatan dikumen digunakan untuk cara memperoleh data dengan jalan mengumpulkan segala macam dokumen dan melakukan pencatatan secara sistematis. (4) Metode tes tertulis merupakan cara mengetahui pengetahuan, keterampilan, intelegensi, atau kemampuan yang dimiliki oleh siswa dengan menggunakan serentetan pertanyaan yang berupa tes objektif (Agung, 2014:240). Instrumen yang digunakan untuk mengumpulkan data dalam penelitian pengembangan ini adalah (1) lembar pencatatan dokumen, (2) lembar kuesioner (angket), dan (3) soal-soal tes pilihan ganda. Lembar pencatatan dokumen digunakan untuk mengumpulkan dokumen-dokumen terkait dengan data rancang bangun pengembangan produk berdasarkan wawancara dengan guru mata pelajaran IPA berupa nilai hasil UTS siswa kelas VII, Silabus, dan RPP. Hasil instrumen pencatatan dokumen ini nantinya akan akan dibentuk berupa laporan pengembangan produk bahan ajar $e$-modul.

Dalam penelitian pengembangan ini digunakan tiga teknik analisis dalam yaitu teknik analisis deksripitif kualitatif, teknik deksriptif kuantitatif, dan teknik analisis statistik inferensial (uji-t).

$$
\text { Persentase }=\frac{\sum(\text { jawaban } \mathrm{x} \text { bobot tiap pilihan })}{n \times \text { bobot terting } i} \times 100 \%
$$

Keterangan:

$\sum \quad=$ jumlah

$\mathrm{n} \quad=$ jumlah seluruh item angket

(Tegeh dan Kirna, 2010:101)

Kemudian untuk menghitung persentase keseluruhan subjek digunakan rumus.

Persentase $=\mathrm{F}: \mathrm{N}$

Keterangan:

$\mathrm{F} \quad=$ Jumlah persentase keseluruhan subjek

$\mathrm{N}$ = banyak subjek

(Tegeh dan Kirna, 2010:101)

Untuk dapat memberikan makna dan pengambilan keputusan digunakan ketetapan sebagai berikut.

Tabel 1. Konversi PAP Tingkat Pencapaian dengan skala 5

\begin{tabular}{lll}
\hline Tingkat Pencapaiaan \% & Kualifikasi & Keterangan \\
\hline $90 \%-100 \%$ & Sangat baik & Tidak perlu direvisi \\
$75 \%-89 \%$ & Baik & Sedikit revisi \\
$65 \%-74 \%$ & Cukup & Direvsi secukupnya \\
$55 \%-64 \%$ & Kurang & Banyak direvisi \\
$0-54 \%$ & Sangat kurang & Revisi total \\
\hline
\end{tabular}

Metode analisis statistik inferensial adalah "cara pengolahaan data yang dikerjakan dengan mempergunkan rumus-rumus statistik inferensial untuk menguji suatu hipotesis penelitian yang diajukan peneliti, dan kesimpulan ditarik berdasarkan hasil pengujian terhadap hipotesis (Agung, 2015=4:110). Data uji coba sasaran yang dikumpulkan dengan menggunakan uji-t untuk mnegetahui perbedaan antara hasil pretest dan posttest.

Sebelum melaksanakan uji hipotesis (uji-t) berkorelasi) dilaksanakan uji prasyarat (uji normalitas dan homogenitas), Uji normalitas dilakukan untuk mengetahui apakah sebaran skor pada setiap variabel berdistribusi normal atau tidak, untuk dapat digunakan rumus Lilifours.

Menurut Koyan (2012:109) adapun cara yang dapat dilakukan untuk menguji normalitas suatu data dengan teknik liliefors yaitu sebagai berikut. (a) Urutkan data sampel dari kecil ke besar dan tentukan frekuensi setiap data. (b) Tentukan nilai z dari setiap data. (c) Tentukan besar peluang untuk setiap nilai z berdasarkan tabel $\mathrm{z}$ dan diberi nama $\mathrm{F}(\mathrm{z})$. (d) Hitung frekuensi kumulatif relatif dari setiap nilai z yang disebut dengan $\mathrm{S}(\mathrm{z}) \rightarrow$ Hitung proporsinya, kalau $\mathrm{n}=20$, maka setiap frekuensi kumulatif dibagi dengan $\mathrm{n}$. Gunakan nilai $L_{0}$ yang terbesar. (e) Tentukan nilai $\mathrm{L}_{0}=|\mathrm{F}(\mathrm{z})-\mathrm{S}(\mathrm{z})|$, hitung selisihnya, kemudian bandingkan dengan nilai $\mathrm{L}_{\mathrm{t}}$ dari tabel Lilifors. (f) Jika $\mathrm{L}_{0}<\mathrm{L}_{\mathrm{t}}$, maka $\mathrm{H}_{0}$ diterima, sehingga dapat disimpulkan bahwa sampel berasal dari populasi yang berdistribusi normal 
Untuk homogenitas ini dilaksanakan untuk mencari tingkat kehomogenan secara dua pihak yang diambil dari kelompok data pisah dari satu sampel untuk mengujii homogenitas varians data sampel digunakan uji Fisher (F) dengan rumus sebagai berikut.

$$
F_{\text {hitung }}=\frac{\text { Varians terbesar }}{\text { Varians terkecil }}
$$

(Koyan, 2012:34)

Kriteria pengujiian tolak $\mathrm{H}_{0}$ jika $\mathrm{F}_{\text {hitung }}<\mathrm{F}_{\text {tabel }}$ yang berarti sampel homogen. Uji dilakukan pada taraf signifikan $5 \%$ dengan derajat kebebasan untuk pembilang $n_{1}-1$ dan derajat kebebasan untuk penyebut $n_{2}-1$.

Teknik analisis yang digunakan untuk pengujian hipotesis adalah teknik analisis uji-t berkorelasi. Dasar penggunaan teknik uji-t berkorelasi ini adalah menggunakan dua perlakuan yang berbeda terhadap satu sampel. Pada penelitian ini akan mengujii perbedaan hasil belajar IPA sebelum dan sesudah menerapkan $e$-modul IPA bermuatan tes online terhadap satu kelompok. Rumus untuk uji-t berkorelasi sebagai berikut.

$$
t=\frac{\bar{X}_{1}-\bar{X}_{2}}{\sqrt{\frac{s_{1}^{2}}{n_{1}}+\frac{s_{2}^{2}}{n_{2}}-2 r\left(\frac{S_{1}}{\sqrt{n_{1}}}\right)\left(\frac{S_{2}}{\sqrt{n_{2}}}\right)}}
$$

(Koyan, 2012:29)

Keterangan:

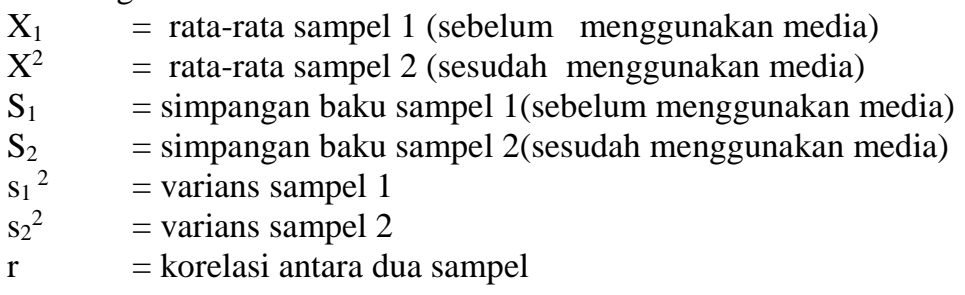

Hasill uji coba dibandingkan $\mathrm{t}_{\text {tabel }}$ dengan taraf signifikan 0,05 (5\%) untuk mengetahui apakah ada perbedaan antara sebelum dan sesudah menggunakan $e$-modul bermuatan tes online.

\section{Hasil dan Pembahasan}

Penelitian pengembangan ini menghasilkan produk berupa bahan ajar e-modul IPA yang dilengkapi dengan petunjuk penggunaan media, serta RPP sebagai acuan pembelajaran. Media ini dikembangkan untuk memfasilitasi guru untuk mengajar siswa kelas VII agar dapat belajar secara mandiri.

Pengembangan $e$-modul IPA bermuatan tes online ini telah melewati beberapa tahap uji coba validitas yang terdiri dari uji ahli isi mata pelajaran, uji ahli desain pembelajaran, uji ahli media pembelajaran, uji coba perorangan, uji coba kelompok kecil, dan uji lapangan. Adapun hasil dari uji ahli dapat dilihat pada tabel 2.

Tabel 2. Persentase Hasil Pengembangan E-Modul

\begin{tabular}{clll}
\hline No & \multicolumn{1}{c}{ Subjek Uji Coba } & Hasil Validitas (\%) & Kualifikasi Persentase \\
\hline 1. & Ujii Ahli Isi Mata Pelajaran & 98 & Sangat baik \\
2. & Uji Ahli Media Pembelajaran & 90,3 & Sangat baik \\
3. & Uji Ahli Desain Pembelajaran & 96,4 & Sangat baik \\
4. & Uji Coba Perorangan & 91 & Sangat baik \\
5. & Uji Coba Kelompok Kecil & 91,05 & Sangat baik \\
6. & Uji Lapangan & 94 & Sangat baik \\
\hline
\end{tabular}

Uji normalitas dilakukan penyebaran soal tes untuk mengetahui data hasil belajar siswa pada $e$-modul IPA bermuatan tes online yang terdiri dari dua tahapan yaitu, (1) penyebaran soal tes sebelum menggunakan $e$ modul IPA (pretest), (2) tahap penyebaran soal tes sesudah menggunakan e-modul IPA (posttest). 
Tabel 3. Hasil Uji Normalitas Pretest dan posttest

\begin{tabular}{|c|c|c|c|c|}
\hline No & Kelompok Data Hasil Belajar & $\mathbf{L}_{0}$ & $\mathbf{L}_{\mathbf{t}}$ & Status \\
\hline 1. & Pretest & -0.1112 & 0.1478 & Normal \\
\hline 2. & Posttest & -0.1611 & 0.1478 & Normal \\
\hline
\end{tabular}

Hasil uji normalitas pretest tersebut diperoleh $\mathrm{L}_{0}=-0.1112<\mathrm{L}_{\mathrm{t}}=0.1478$ maka $\mathrm{H}_{0}$ diterima, sehingga dapat disimpulkan bahwa sampel berasal dari populasi yang berdistribusi normal. Sedangkan hasil dari uji normalitas posttest siswa tersebut diperoleh $\mathrm{L}_{0}=-0.1611<\mathrm{L}_{\mathrm{t}}=0.1478$ maka $\mathrm{H}_{0}$ diterima, sehingga dapat disimpulan bahwa sampel berasal dari populasi yang berdistribusi normal.

Uji homogenitas ini dimaksudkan untuk mencari bahwa dua atau lebih kelompok data sampel berasal dari populasi yang memiliki variasi yang sama. Hasil perhitungan didapatkan varians pretest 141,7 dan varians posttest 56,6. Untuk menguji homogenitas varians data sampel digunakan uji $\mathrm{F}$ dengan rumus sebagai berikut.

$$
\mathrm{F}_{\text {hit }}=\frac{141.7}{56.6}=2.50
$$

Sehingga dapat disimpulkan bahwa $F_{\text {hitung }} \leq F_{\text {tabel (n1-1, n2-1) yaitu }} F_{\text {hitung }}(2,50) \leq F_{\text {tabel }}(4,13)$ sehingga $\mathrm{H}_{0}$ diterima yang berarti sampel bersifat homogen.

Berdasarkan hasil pengujian normalitas dan homogenitas diperoleh bahwa data tersebut bersifat normal dan homogen, maka perlu dilakukan uji hipotesis dengan menggunakan rumus uji-t. sebelum masuk ke uji-t, dilakukan perhitungan korelasi antara variable $\mathrm{X}$ dan $\mathrm{Y}$ dengan menggunakan rumus produck moment, yang mana hasil dari perhitungan tersebut mendapatkan hasil 0.531. setelah korelasi $\mathrm{r}_{\mathrm{xy}}$, kemudian masuk pada uji-t. Berdasarkan hasil uji-t diperoleh $t_{\text {hitung }}=-31,27$ untuk $\mathrm{db}=68$ dan taraf signifikani5\%, $\mathrm{t}_{\text {tabel }}=1,667$. Hali ini berarti $t_{\text {hitung }}>\mathrm{t}$ tabel, sehingga $\mathrm{H}_{0}$ ditolak dan $\mathrm{H}_{1}$ diterima. Berdasarkan kriteria pengujian, $\mathrm{H}_{0}$ ditolak dan $\mathrm{H}_{1}$ diterima yang artinya terdapat perbedaan yang signifikan (5\%) hasil belajar sebelum dan sesudah menggunakan e-modul IPA bermuatan tes online pada siswa kelas VII D di SMP Negeri 3 Singaraja. Sehingga dapat diinterpretasikan bahwa $e$-modul IPA bermuatan tes online efektif meningkatkan hasil belajar IPA pada siswa.

Pengembangan $e$-modul IPA bermuatan tes online ini dilakukan dengan menggunakan model ADDIE, yang mana meliputi tahapan analisis, tahap desain, tahap pengembangan, tahap implementasi, dan tahap evaluasi. Rancang bangun pengembangan e-modul IPA bermuatan tes online ini mengacu pada model ADDIE yang meliputi 5 tahap. Tahap pertama yang dilakukan adalah tahap analisis. Pada tahap ini dilakukan pengenalan karakteristik siswa, analisis kompetensi, dan analisis lingkungan sekolah. Analisis karakteristik siswa dilakukan dengan metode observasi dan metode wawancara. Metode wawancara dan observasi dilakukan saat pembelajaran dikelas, disimpulkan bahwa karakteristik siswa memiliki pengetahuan tinggi, sedang dan rendah.

Pada analisis kompetensi dilakukan pemilihan materi pembelajaran yang relevan dengan produk yang akan dikembangkan serta analisis karakteristik dan kemampuan yang dimiliki siswa. Analisis instruksional yang dilakukan terkait dengan kompetensi yang dituntut tercapai pada peserta didik dimulai dari analisis kompetensi inti, dan kompetensi dasar, analisis bahan ajar, serta pemilihan dan penentuan bahan ajar. Pada tahap analisis fasilitas dan lingkungan dilakukan observasi di SMP Negeri 3 Singaraja. Hasil analisis fasilitas dan lingkungan tersebut menunjukkan bahwa sebagian siswa sudah memiliki laptop dan smartphone dengan system operasi android. Disamping itu fasilitas yang ada di SMP Negeri 3 Singaraja sudah cukup lengkap yaitu LCD di setiap kelas, Laboratorium komputer, akses internet. Hal tersebut menjadi aspek pendukung pengembangan e-modul ini.

Tahap kedua adalah desain. Pada tahap ini yang dilakukan dalam pengembangan e-modul IPA adalah melakukan perancangan. hal yang harus dilakukan yaitu membuat peta konsep e-modul, membuat kerangka $e$ modul, desain tampilan e-modul, flowchart dan storyboard, instrumen penilaian, kisi-kisi butir soal dan menyusun RPP. Tahap yang ketiga adalah pengembangan. Pengumpulan bahan atau materi bahan ajar, adapun bahan tersebut didapatkan dari buku ajar IPA kelas VII dan buku-buku lainnya yang relevan dengan materi yang diangkat pada $e$-modul.

Tahap keempat adalah tahap implementasi. Sebelum melakukan implementasi terlebih dulu dilakukan uji ahli tujuannya untuk mengetahui respon dari ahli isi mata pelajaran, ahli media pembelajara dan ahli desain pembelajaran serta siswa yang dilihat dari segi kemenarikan dan kelayakannya. Hasil implementasi berupa validasi yang dilakukan oleh ahli isi mata pelajaran, ahli media pembelajaran dan ahli desain pembelajaran. sedangkan untuk uji coba produk meliputi (a) uji perorangan yang melibatkan 3 (tiga) orang siswa kelas VIII, Ketiga siswa ini terdiri dari satu orang siswa yang memiliki nilai belajar tinggi, satu orang siswa yang memiliki nilai belajar sedang, dan satu orang siswa yang memiliki nilai belajar rendah. (b) uji coba kelompok kecil mengikutsertakan 9 orang siswa kelas VIII, tiga orang siswa yang memiliki nilai belajar tinggi, tiga orang siswa yang memiliki nilai belajar sedang dan tiga orang siswa yang memiliki nilai belajar rendah. Sedangkan uji coba lapangan melibatkan 35 (tiga puluh lima) orang siswa kelas VII. 
Tahap evaluasi, pada tahap ini dilakukan analisis pada hasil evaluasi formatif dan evaluasi sumatif yang terkumpul dari implementasi guna mengevaluasi pengembangan produk dan efektivitas produk dalam meningkatkan hasil belajar siswa. Adapun hasil evaluasi formatif yang akan di analisis berupa penilaian dari validasi ahli, uji coba perorangan, kelompok kecil, dan lapangan, sehingga didapatkan perbaikan produk. Sedangkan hasil evaluasi sumatif dilakukan guna mengetahui efektivitas produk yang dikembangkan dalam meningkatkan hasil belajar siswa dengan melakukan tahap uji efektivitas.

Setelah tahap pengembangan media selesai dikerjakan, langkah berikutnya melakukan validitas terhadap media yang dikembangkan. Validitas dilakukan dengan melakukan review dari ahli isi mata pelajaran mendapat persentase $98 \%$ dengan kategori sangat baik. Dikatakan sangat baik karena E-Modul IPA sudah sesuai dengan materi kelas VII semester ganjil dan video pada E-Modul sudah sesuai. Sesuai dengan desain pesan pembelajaran menurut (Sudarma, dkk 2015), mengatakan bahwa pada bagian ini materi $e$-modul dikembangkan sesuai dengan karakteristik siswa dan konten pada materi $e$-modul menggunakan unsur multimedia seperti teks, gambar, audio, dan video.

Selanjutnya, review ahli desain pembelajaran mendapatkan presentase 96,4\% dengan kategori sangat baik. Dikatakan sangat baik karena aspek perumusan dan tujuan pembelajaran sudah dikembangkan berdasarkan kompetensi inti dan kompetensi dasar. Ahli media pembelajaran mendapatkan presentase $90,3 \%$ dengan kategori sangat baik. Dikatakan sangat baik karena salah satunya dalam desain pesan teks pada $e$-modul sudah memperhatikan prinsip desain pesan.

Uji coba perorangan mendapatkan presentase 91\% kategori sangat baik, uji coba kelompok kecil 91,5\% kategori sangat baik, dan uji lapangan mendapatkan presentase 94\% dengan kategori sangat baik sehingga layak digunakan layak untuk diuji di kelas penelitian. Uji normalitas dilakukan untuk membuktikan bahwa sampel benar-benar berasal dari populasi yang berdistribusi normal. Uji normalitas dilakukan dua tahap yaitu tahap pretest dan tahap posttes. Tahap pretest dilakukan sebelum menggunakan e-modul IPA dan tahap posttest dilakukan setelah menggunakan $e$-modul IPA. Setelah itu dilakukan perhitungan dengan menggunakan teknik Liliefors, pretest diperoleh $\mathrm{L} 0=-0.1112<\mathrm{Lt}=0.1478$ dan posttest diperoleh $\mathrm{L} 0=-0.1611<\mathrm{Lt}=0.1478$ dengan taraf Liliefors 5\% maka H0 diterima. Dengan demikian semua hasil data skor hasil belajar siswa (pretest dan posttest) pada e-modul IPA berdistribusi normal. Uji homogenitas ini dimaksudkan untuk mencari bahwa dua atau lebih kelompok data sampel berasal dari populasi yang memiliki variasi yang sama. data yang digunakan untuk uji homogenitas yanitu hasil belajar pretast dan posttest. Hasil perhitungan Fhitung $\leq$ Ftabel (n1-1, n2-1) yaitu Fhitung $(2,50) \leq$ Ftabel $(4,13)$ sehingga kedua data memiliki sampel yang bersifat homogen.

Berdasarkan hasil pengujian normalitas dan homogenitas diperoleh bahwa data berdistribusi normal dan homogen. Berdasarkan hal tersebut, langkah selanjutnya yaitu uji hipotesis dengan menggunakan uji t-test. Pengujian hipotesis dilakukan dengan analisis uji-t sampel berkorelasi. Semua pengujian hipotesis dilakukan pada taraf signifikansi $5 \%$. Kriteria pengujian adalah apabila hasil perhitungan diperoleh nilai thitung $>\mathrm{t}_{\text {tabel }}$ maka H0 ditolak dan H1 diterima. Dari hasil uji-t yang sudah diperoleh $t_{\text {hitung }}$ yaitu $-31,27$ dan $t_{\text {tabel }}$ yaitu 1,667 untuk derajat kebebasan $(\mathrm{db})$ yaitu 68 dari taraf signifikan 5\%. Hal ini berarti $\mathrm{t}_{\text {hitung }}>$ ttabel sehingga H0 ditolak dan $\mathrm{H} 1$ diterima.

Berdasarkan kriteria pengujian, H0 ditolak dan $\mathrm{H} 1$ diterima yang artinya terdapat perbedaan yang signifikan (5\%) hasil belajar sebelum dan sesudah menggunakan e-modul IPA bermuatan tes online pada siswa kelas VIID di SMP Negeri 3 Singaraja. Sehigga dapat diinterpretasikan bahwa $e$-modul IPA bermuatan tes online efektif meningkatkan hasil belajar IPA pada siswa.

\section{Simpulan}

Simpulan dalam penelitian pengembangan ini terdiri dari tiga hal yaitu: (1) rancang bangun E-Modul IPA bermuatan tes online dikembangkan pada semua tahapan dari model pengembangan ADDIE. Pengembangan dimulai dari: (a) tahap analysis (analisis), (b) tahap design (perancangan), (c) tahap depelopment (pengembangan), (d) tahap implementation (implementasi), dan (e) tahap evaluation (evaluasi). Analisis kebutuhan dilakukan dengan melakukan observasi dan wawancara terhadap guru mata pelajaran IPA dan siswa Kelas VII di SMP Negeri 3 Singaraja. Selanjutnya dilakukan tahap desain yang meliputi: 1) membuat peta konsep e-modul, digunakan untuk acuan dalam mengembangkan isi dari keseluruhan $e$-modul dengan memperhatikan urutannya, 2) kerangka $e$-modul meliputi garis besar e-modul dan sistematika penyusunan materi, 3) menetapkan desain tampilan $e$-modul, meliputi rancangan tampilan sampul/cover, jenis huruf, ukuran huruf, spasi, dan pewarnaan dalam e-modul, 4) membuat flowchart e-modul, 5) menyusun instrumen penilaian e-modul, 6) membuat kisi-kisi soal dan butir soal, dan 7) menyusun RPP. Pada tahap pengembangan E-Modul IPA dari wujud desain dikembangkan menjadi produk yang sesungguhnya pada tahap ini akan menghasilkan produk. Tahap selanjutnya yakni tahap implementasi. Pada tahap ini difokuskan untuk mengimplementasikan produk yang dibuat setelah melalui proses analisis desain, dan pengembangan. Implementasi dalam hal ini dimaksudkan untuk menerapkan efisiensi dan efektivitas produk yang telah diimplementasikan dilapangan. Dalam proses implementasi melibatkan seluruh komponen yang menjadi fokus tujuan dari pembuatan produk $E$ - 
Modul IPA. Pada tahap akhir penilaian dilakukan untuk memvalidasi produk yang telah dibuat melalui uji ahli produk. Uji validasi produk bertujuan untuk menguji-tingkat keajegan produk yang sudah dibuat, sedangkan uji efektivitas bertujuan untuk mengukur tingkat efektivitas produk yang dibuat. Uji validasi produk bertujuan untuk menguji-tingkat keajegan produk yang sudah dibuat. (2) Hasil uji coba pengembangan E-Modul IPA pada (a) ahli isi mata pelajaran berpredikat sangat baik (98\%), (b) ahli desain pembelajaran berpredikat sangat baik (96,04\%), (c) ahli media pembelajaran berpredikat sangat baik $(90,03 \%)$, (d) uji coba perorangan berpredikat sangat baik (91\%), (e) uji coba kelompok kecil berpredikat sangat baik $(91,05 \%)$, dan (f) uji coba lapangan berpredikat sangat baik (94\%). (3) Hasil uji efektivitas yang dianalisis dengan teknik analisis statistik inferensial (uji-t) menemukan bahwa hasil uji-t diperoleh $\mathrm{t}_{\text {hitung }}=-31,27 \mathrm{dan} \mathrm{t}_{\text {tabel }}=1,667$ untuk db $=68$ dari taraf signifikans $5 \%$. Hal ini berarti $\mathrm{t}_{\text {hitung }}>\mathrm{t}_{\text {tabel}}$, sehingga $\mathrm{H}_{0}$ ditolak dan $\mathrm{H}_{1}$ diterima. Dengan demikian dapat disimpulkan bahwa E-Modul IPA bermuatan tes online terbukti efektif secara signifikan dapat meningkatkan hasil belajar IPA siswa kelas VII tahun pelajaran 2019/2020 di SMP Negeri 3 Singaraja.

Saran yang disampaikan dalam pengembangan E-Modul IPA bermuatan tes online yaitu: (1) Disarankan kepada siswa, agar dapat memanfaatkan e-modul secara optimal. E-Modul tidak hanya dimanfaatkan di sekolah saja, namun dapat dimanfaatkan dimana dan kapan saja pada saat siswa ingin belajar. Dengan pemanfaatan $E$ Modul IPA secara maksimal, maka diharapkan hasil belajar siswa akan meningkat lebih optimal, (2) Disarankan kepada guru mata pelajaran khususnya mata pelajaran IPA, yakni hasil penelitian ini dapat digunakan sebagai salah satu alternatif model pembelajaran untuk menciptakan pemahaman yang lebih cepat terhadap proses pembelajaran dan menggunakan $e$-modul sebagai salah satu media pembelajaran yang dapat membangkitkan minat belajar siswa dan membuat pembelajaran lebih efektif lagi, (3) Disarankan kepada sekolah, agar guruguru dapat mengembangkan kreativitas dan lebih mengaktifkan siswa dalam proses belajar mengajar melalui model-model pembelajaran yang inovatif. Selain itu pihak sekolah juga harus menambah sarana dan prasarana penunjang proses pembelajaran agar proses pembelajaran nantinya lebih efektif dan mampu menambah daya tarik siswa dalam memahami materi pembelajaran, dan (4) Disarankan kepada peneliti lain, yakni hasil penelitian ini dapat dimanfaatkan untuk mendapatkan pengalaman langsung dan dapat dijadikan informasi bagi para peneliti bidang pendidikan untuk meneliti aspek atau variabel dan dijadikan sebagai referensi untuk melakukan penelitian sejenis sebagai pedoman untuk melakukan penelitian pengembangan yang lebih menarik dan inovatif.

\section{Daftar Pustaka}

Agung, A. A. Gede. 2014. Metodologi Penelitian Pendidikan. Buku Ajar Metodologi Penelitian Pendidikan. Singaraja: Undiksha.

Arsyad, A. (2011). Media pembelajaran. Jakarta: PT Raja Grafindo Persada.

Getuno, D. M., Kiboss, J. K., Changeiywo, J. M., \& Ogola, L. B. (2015). Effects of an E-Learning Module on Students' Attitudes in an Electronics Class. Journal of Education and Practice, 6(36), 80-86.

Koyan, I. W. 2012. Statistik Pendidikan. Singaraja: Undiksha

Munthe, B. (2009). Desain pembelajaran. Yogyakarta: Pustaka Insani Madani.

Sadiman, A.S., dkk. 2006. Media Pendidikan. Jakarta : Raja Grafindo Persada.

Sudarma, dkk., 2015. Desain Pesan: Kajian Analisis Desain Visual (Teks dan Image). Yogyakarta: Graha Ilmu.

Tegeh, I. M. dkk. (2014). Model penelitian pengembangan. Yogyakarta: Graha Ilmu.

Tegeh, I.M,. \& Kirna. I.M. 2010. Metode Penelitian Pengembangan Pendidikan. Buleleng. Singaraja: Universitas Pendidikan Ganesha.

Wirawan, I. K. Y. A. P., dkk. 2017. "Pengembangan E-Modul Berbasis Problem Based Learning Untuk Mata Pelajaran IPA Siswa Kelas VII Semester Ganjil”. Teknologi Pendidikan. (Vol: 8 No: 2 Tahun 2017). Di akses pada tanggal 24 Juni 2018. 